\title{
Tsunami effects on the Coast of Mexico by the Hunga Tonga-Hunga Ha'apai volcano eruption, Tonga
}

\author{
María Teresa Ramírez-Herrera ${ }^{l}$ \\ Oswaldo Coca ${ }^{2}$ \\ Victor Vargas-Espinosa ${ }^{3}$ \\ ${ }^{1}$ Universidad Nacional Autónoma de México, Instituto de Geografía, Lab. de Tsunamis y \\ Paleosismología,Cd.De México, México, maria_teresa_ramirez@yahoo.com, https://orcid.org/0000- \\ $\underline{0001-6131-0246}$ \\ ${ }^{2}$ Postgrado en Geografía, Instituto de Geografía, Universidad Nacional Autónoma de México, Cd. De \\ México, México \\ https://orcid.org/0000-0002-3987-4376 \\ ${ }^{3}$ Postgrado en Ciencias del Mar y Limnología, Instituto de Ciencias del Mar y Limnología, \\ Universidad Nacional Autónoma de México, Cd. De \\ México, México
}

This paper is a non-peer reviewed preprint submitted to EarthArXiv. This preprint was submitted to Pure and Applied Geophysics journal for peer review on February 3, 2022.

Twitter: @TeresaRamirezH 


\section{Abstract}

The massive explosion by the January 14, 2022 Hunga Tonga-Hunga Ha'apai volcano in Tonga triggered a transoceanic tsunami generated by coupled ocean and atmospheric shock waves during the explosion. The tsunami reached first the coast of Tonga, and later many coasts around the world. The shock wave went around the globe, causing sea perturbations as far as the Caribbean and the Mediterranean seas. We present the effects of the January 14, 2022 Tonga tsunami on the Mexican Pacific Coast, Gulf of Mexico, and Mexican Caribbean coast, and discuss the underrated hazard caused by great volcanic explosions, and the role of early tsunami warning systems, in particular in Mexico. The shock wave took about 7.5 hours to reach the coast of Mexico, located about $9000 \mathrm{~km}$ away from the volcano, and the signal lasted several hours, about 133 hours (5.13 days). The first tsunami waves recorded on the Mexican Pacific coast arrived around 06:26 on January 15, at the Huatulco, Oaxaca tide gauge station. The maximum tsunami height exceeded $2 \mathrm{~m}$ at the Ensenada, Baja California, and Manzanillo, Colima, tide gauge stations. Most tsunami warning advisories, with two exceptions, reached communities via social media (Twitter and Facebook), but did not clearly state that people must stay away from the shore. We suggest that, although no casualties were reported in Mexico, tsunami warning advisories of far-field tsunamis and those triggered by volcanic eruptions should be improved and reach coastal communities timely, explaining the associated hazards on the coast.

Keywords: Volcanic explosion, Far-field Tsunami, Shock wave, Tsunami warning, Tonga, Mexico.

\section{Introduction}

Volcanic eruptions are frequent and occur in different parts of the world. However, massive explosions by volcanoes can trigger other hazards such as tsunamis. Tsunamis triggered by volcanic eruptions are generated by submarine landslides and caldera collapses (e.g. Nagai et al., 2021; Maeno and Imamura, 2011; Nomanbhoy and Satake, 1995; Pararas-Carayannis, 1992), and by coupled ocean and atmospheric shock waves during explosions (Bryant, 2001; Pelinovzky et al., 2005; Simkin and Fiske, 1983; Choi, 2003; Yokoyama, 1981). To generate coupled sea-atmospheric waves, volcanic eruptions must be large, e.g. the 1883 Krakatau eruption (Yokoyama, 1981). The latest is the case of the massive explosion by the January 14, 2022 Hunga Tonga-Hunga Ha'apai volcano in Tonga. This kind of massive explosions occur less often. Hunga Tonga-Hunga Ha'apai volcano had a powerful explosion back in 1100 AD, and big eruptions occur every ca. 1000 years (Cronnin et al., 2017). The 2022 generated tsunami reached first the coast of Tonga, and later many coasts around the world, such as those in the Pacific Ocean, and a shock wave that went around 
the globe, and as far as the Caribbean Sea, Mediterranean Sea, and others (PTWC, 2022; NTWC, 2022). Here we present and discuss tsunami effects on the Mexican Pacific Coast, Gulf of Mexico, and Mexican Caribbean coast, the underrated hazard caused by great volcanic explosions, and the role of early tsunami warning systems.

\subsection{Hunga Tonga-Hunga Ha'apai volcano eruption of January 15, 2022}

The Hunga Tonga-Hunga Ha'apai volcano, located approximately $65 \mathrm{~km}$ north of Tongatapu, Nuku'alofa, in the South Pacific Ocean, produced a massive explosion on January 15, 2022, at 17:10 local time (central Mexico time 22:10 January 14), sending a pressure wave around the globe, a huge volcanic plume more than $20 \mathrm{~km}$ high captured on satellite images, and triggering a tsunami that affected not only Tonga but my places across the Pacific (Figure 1). The USGS reported the energy released by the eruption equivalent to a magnitude 5.8 earthquake (USGS, 2022).

The Hunga-Tonga-Hunga-Ha'apai volcano is located along the Tonga-Kermedec Arc, where the Pacific plate subducts under the Indo-Australian plate, in the southwest Pacific. This volcano is largely underwater and is part of a chain of submarine volcanoes and has an approximately $6 \mathrm{~km}$ wide submerged caldera (Cronin, 2017). Recent volcanic eruptions in 2009, 2014, and 2015 (Cronin, 2017; 2022) showed the activity of this volcano, most recently initiated in December 2021 just before the January 15, 2022 massive explosion.

\subsection{Shock wave and Tsunami}

The blast from the shock wave or pressure wave (produced by sudden change in pressure) generated by the volcanic explosion traveled large distances in the air at more than 1000 kilometers per hour and was recorded globally, crossing Australia, Asia, UK, Europe, the Americas (Klein, 2022), and in Mexico it was captured at several weather stations (Servicio Meteorológico Nacional - SMN, 2022).

The tsunami triggered by the eruption of this submarine volcano inundated coastal areas and reached a height of 83 centimeters in Nuku'alofa, according to the Pacific Tsunami Warning Center (PTWC, 2022), though the Nuku'alofa tide gauge recorded a tsunami wave of 1.19 meters before it stopped recording (Watkins, 2022). This tsunami generated large waves that first hit the coast of Tonga, locally reporting waves as high as $15 \mathrm{~m}$ (Government of Tonga, 2022) reaching as far as Japan (1.1 meters; PTCWC, 2022) Chile, Peru (PTWC, 2022), California (1.1 meters; NOAA, 2022), and Mexico among many others. This tsunami caused severe damage in Tonga, which is still assessed by local 
authorities, and damage has been reported on the Japan coast, California, and in Peru two people died (CNN, 2022) and an oil spill occurred on its coast impacting fauna and the environment (Taj, 2022).

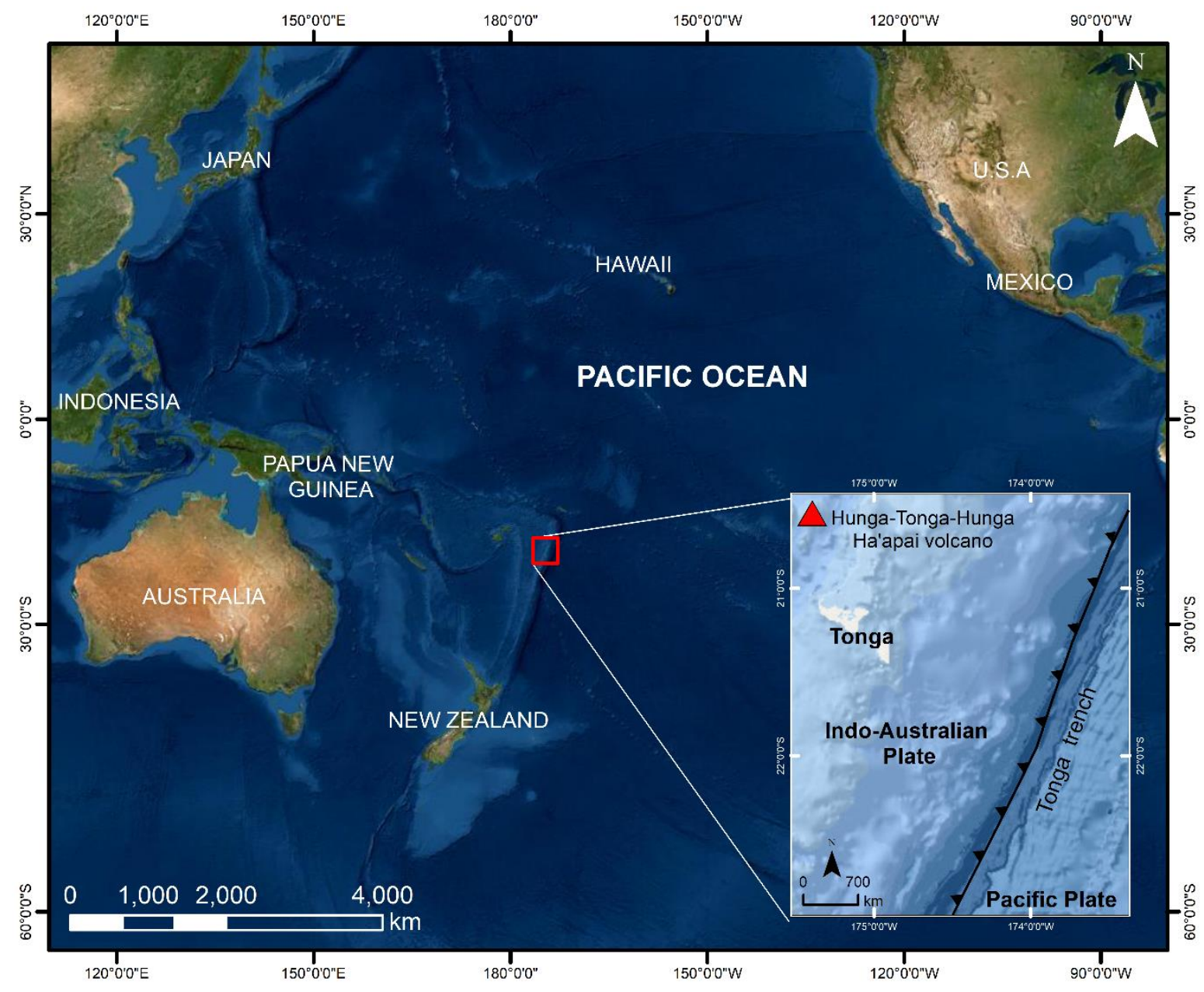

Figure 1. Hunga-Tonga-Hunga Ha'apai volcano tectonic setting.

\section{Data and Methods}

Tsunami data was obtained from tide gauge stations from the National Tide Gauge Service (Servicio Mareográfico Nacional - SMN, for its acronym in Spanish) (SMN, 2022). Atmospheric pressure data were retrieved from the Automatic Weather Stations (Estaciones Meteorológicas Automáticas - "EMA" for its acronym in Spanish) from National Weather Service (Servicio Meteorológico Nacional - SMN - Spanish acronym) at Comisión Nacional del Agua - CONAGUA (SMN-CONAGUA, 2022) (Figure 2). 
Data collection on Tsunami Warning advisories, effects, casualties, and other relevant information from news online, from social media (Twitter, Facebook, YouTube) and official internet sites.

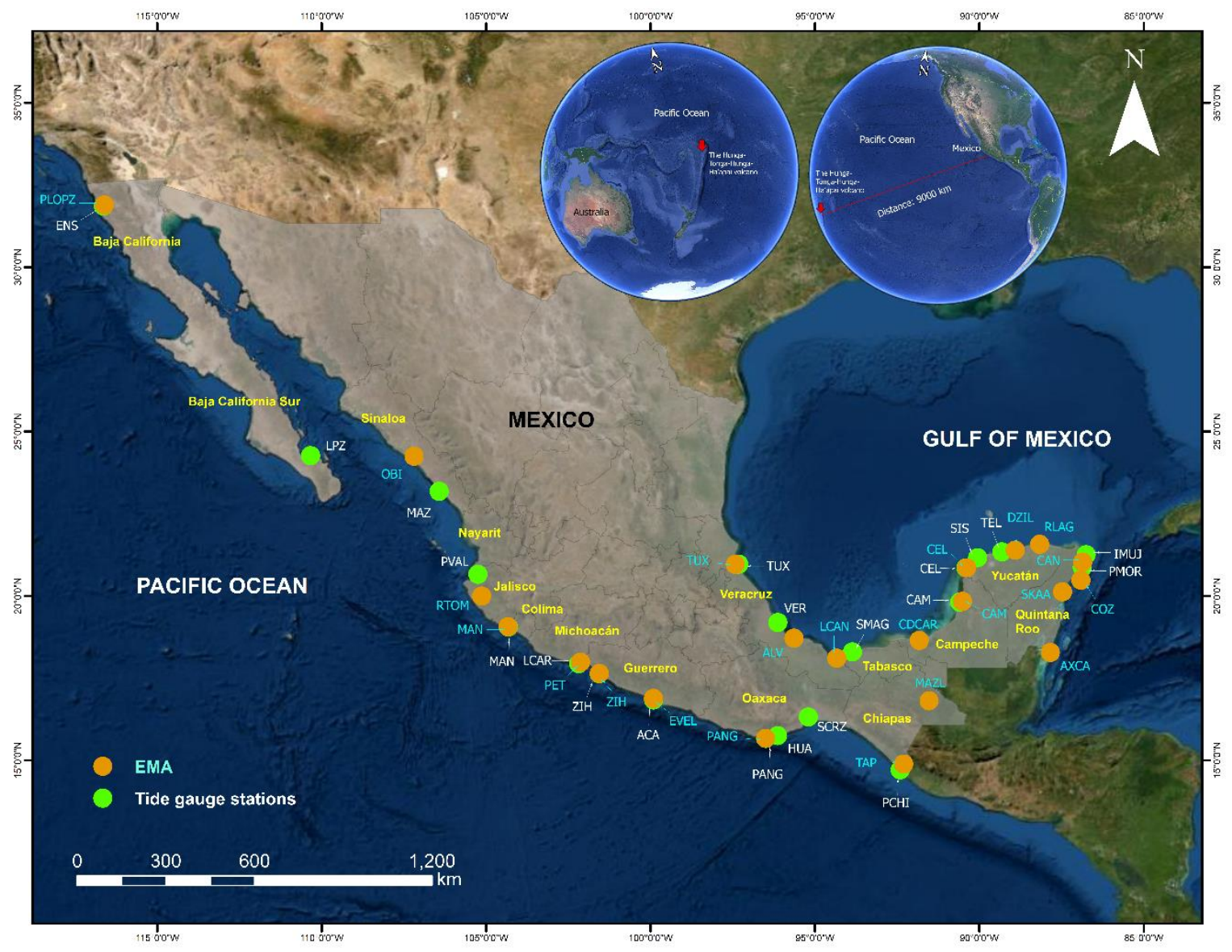

Figure 2. National Tide Gauge Service (SMN) and Automatic Weather Stations (EMA) stations on the Mexican coast.Automatic Weather Stations "EMA" - orange points, source: SMN-CONAGUA (2022), and tide gauge stations from the National Tide Gauge Service "SMN" - green points (SMN, 2022). EMA stations: PLOPZ (Presa López Zamora), OBI (Obispo), RTOM (Río Tomatlán), MAN (Manzanillo), PET (Petacalco), ZIH (Zihuatanejo), EVEL (El Veladero), PANG (Puerto Ángel), TAP (Tapachula), MAZL (Montes Azules), AXCA (Arrecife Xcalak), SKAA (Sian Kaan), COZ (Cozumel), CAN (Cancún), RLAG (Río Lagartos), DZIL (Dzilam), CEL (Celestún), CAM (Campeche), CDCAR (Ciudad del Carmen), LCAN (La Cangrejera), ALV (Alvarado) y TUX (Tuxpan). The tide gauge stations: ENS (Ensenada), LPZ (La Paz), MAZ (Mazatlán), PVAL (Puerto Vallarta), MAN (Manzanillo), LCAR (Lázaro Cárdenas), ZIH (Zihuatanejo), ACA (Acapulco), HUA (Huatulco), PANG (Puerto Ángel), PCHI (Puerto Chiapas), PMOR (Puerto Morelos), IMUJ (Isla Mujeres), TEL (Telchac), SIS 
(Sisal), CEL (Celestún), CAM (Campeche), SMAG (Sánchez _ Magallanes), VER (Veracruz) y TUX (Tuxpan). Inserts show the average distance between the Hunga-Tonga-Hunga-Ha'apai Volcano and Mexico. Data source: CONAGUA and SMN.

\section{Effects in Mexico by the eruption-triggered tsunami in Tonga \\ 3.1 Tide gauge and pressure wave data}

\subsubsection{Shock wave}

The shock wave generated by the eruption was recorded by several weather and infrasound stations around the globe. It took about 7.5 hours to be recorded at weather stations in Mexico located about $9000 \mathrm{~km}$ away from the volcano eruption. The shock wave signal was captured by CONAGUA weather stations along the Pacific coast, at the Gulf of Mexico, and Caribbean Sea stations (Servicio Meteorológico Nacional - SMN, 2022). Since the shock wave traveled back and forth from the volcano eruption, and the signal from the shock wave caused by the volcanic explosion lasted several hours, the barometers recorded several peaks (8) for about 133 hours (5.13 days) (Figure 3 and 4 - and Table 1).

Eight pressure wave peaks were recorded at weather stations in Mexico, however, peaks 7 and 8 were no longer recorded at some stations on January 19 and 20. The pressure or shock wave was first recorded on the Mexican coast at the Ensenada (Baja California) station at 06:00 local time, and the last station to record it was Arrecife Xcalak (Quintana Roo) at 07:50 on January 15. Weather stations recorded the hour and day for each one of the peaks, allowing the identification of the shock wave oscillatory motion back and forth (Figure 3 and 4; and Table 1). 
Ramirez-Herrera et al., Tsunami effects on the Coast of Mexico by the Hunga Tonga-Hunga Ha'apai volcano eruption

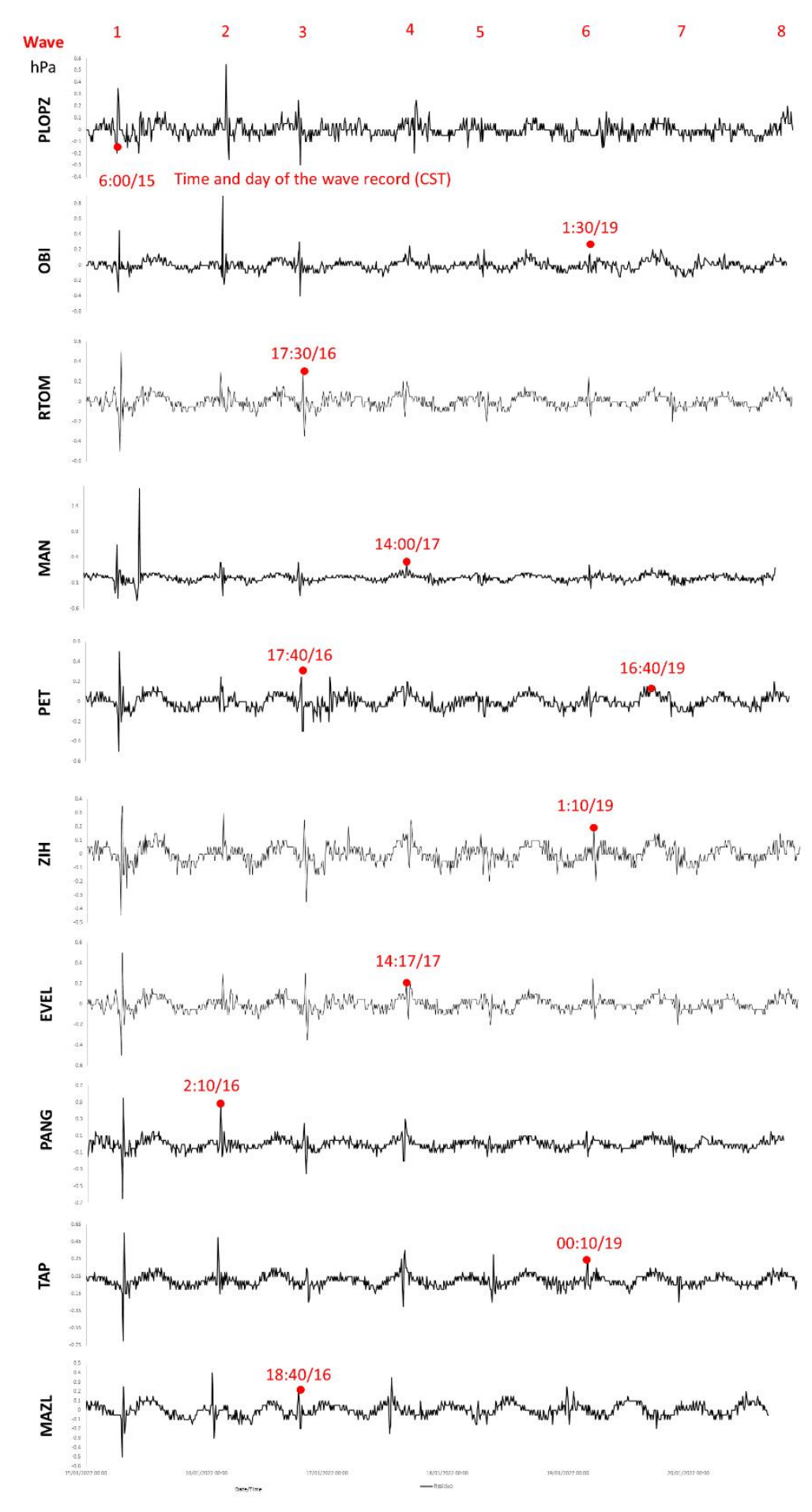

Figure 3. Shock waves recorded at the Mexican Pacific coast. Graphs show shock wave peaks generated by the Hunga-Tonga-Hunga-Ha'apai Volcano explosion (8 peaks). The image also shows examples of the time of recording (time and day - CST time) of the wave peaks (red letters) and the time between the recording of each wave (blue letters). Pacific stations. Source: SMN-CONAGUA (2022). 
Ramirez-Herrera et al., Tsunami effects on the Coast of Mexico by the Hunga Tonga-Hunga Ha'apai volcano eruption

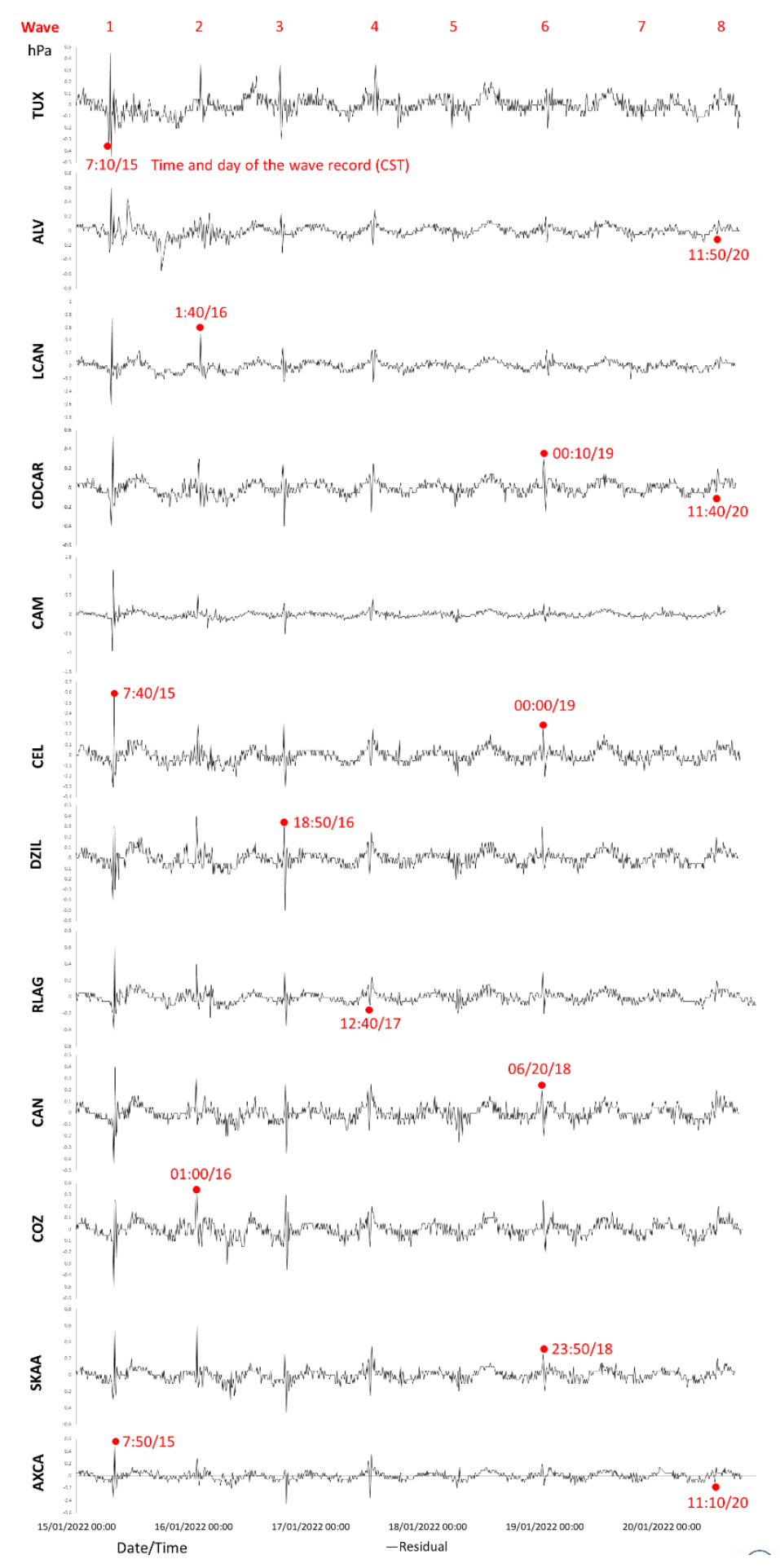

Figure 4. Shock wave peaks for the Gulf of Mexico and Mexican Caribbean Sea. Graphs show shock wave peaks generated by the Hunga-Tonga-Hunga-Ha'apai Volcano explosion ( 8 peaks). The image also shows examples of the time of recording (time and day - CST time) of the wave peaks (red letters) and the time between 
the recording of each wave (blue letters). Gulf of Mexico and Mexican Caribbean stations. Source: SMNCONAGUA (.2022)

Table 1 Weather stations, shock wave, and peak parameters.

\begin{tabular}{|c|c|c|c|c|c|c|c|c|}
\hline Station & $\begin{array}{l}\text { Time/Day } \\
\text { (P1) }\end{array}$ & $\begin{array}{l}\text { Time/Day } \\
\text { (P2) }\end{array}$ & $\begin{array}{l}\text { Time/Day } \\
\text { (P3) }\end{array}$ & $\begin{array}{l}\text { Time/Day } \\
\text { (P4) }\end{array}$ & $\begin{array}{l}\text { Time/Day } \\
\text { (P5) }\end{array}$ & $\begin{array}{l}\text { Time/Day } \\
\text { (P6) }\end{array}$ & $\begin{array}{l}\text { Time/Day } \\
\text { (P7) }\end{array}$ & $\begin{array}{l}\text { Time/Day } \\
\text { (P8) }\end{array}$ \\
\hline \multicolumn{9}{|l|}{ Pacific } \\
\hline PLOPZ & $06: 00 / 15$ & 03:00/16 & $16: 40 / 16$ & $14: 50 / 17$ & & & & \\
\hline OBI & $06: 20 / 15$ & $02: 40 / 16$ & $17: 20 / 16$ & $14: 30 / 17$ & $04: 50 / 18$ & $01: 30 / 19$ & & \\
\hline RTOM & $06: 20 / 15$ & $02: 40 / 16$ & $17: 30 / 16$ & & & & & \\
\hline MAN & $06: 20 / 15$ & $02: 40 / 16$ & $17: 20 / 16$ & $14: 00 / 17$ & $04: 10 / 18$ & $01: 10 / 19$ & & \\
\hline PET & $06: 30 / 15$ & $02: 40 / 16$ & $17: 40 / 16$ & $14: 00 / 17$ & $04: 30 / 18$ & $01: 10 / 19$ & $16: 40 / 19$ & \\
\hline $\mathrm{ZIH}$ & $06: 30 / 15$ & $02: 40 / 16$ & $17: 50 / 16$ & $14: 00 / 17$ & $04: 40 / 18$ & $01: 10 / 19$ & $16: 40 / 19$ & \\
\hline EVEL & $06: 40 / 15$ & $02: 40 / 16$ & $17: 50 / 16$ & $14: 00 / 17$ & $04: 50 / 18$ & 01:00/19 & $16: 50 / 19$ & $12: 20 / 20$ \\
\hline PANG & $06: 50 / 15$ & $02: 10 / 16$ & $18: 10 / 16$ & $13: 20 / 17$ & $05: 10 / 18$ & $00: 40 / 19$ & $17: 10 / 19$ & $12: 00 / 20$ \\
\hline TAP & $07: 10 / 15$ & $02: 00 / 16$ & $18: 30 / 16$ & $13: 10 / 17$ & $05: 10 / 18$ & $00: 10 / 19$ & $17: 30 / 19$ & $11: 30 / 20$ \\
\hline MAZL & $07: 40 / 15$ & $01: 30 / 16$ & $18: 40 / 16$ & $12: 40 / 17$ & & $00: 10 / 19$ & $17: 40 / 19$ & $11: 30 / 20$ \\
\hline \multicolumn{9}{|c|}{ Caribbean } \\
\hline TUX & $07: 10 / 15$ & 02:00/16 & $18: 00 / 16$ & $13: 20 / 17$ & $04: 20 / 18$ & 00:40/19 & & \\
\hline ALV & $07: 10 / 15$ & $01: 50 / 16$ & $18: 20 / 16$ & $13: 10 / 17$ & & $00: 30 / 19$ & & $11: 50 / 20$ \\
\hline LCAN & $07: 10 / 15$ & $01: 40 / 16$ & $18: 20 / 16$ & $13: 10 / 17$ & & $00: 30 / 19$ & $17: 20 / 19$ & $11: 50 / 20$ \\
\hline CDCAR & $07: 30 / 15$ & $01: 30 / 16$ & $18: 40 / 16$ & $13: 00 / 17$ & $05: 40 / 18$ & $00: 10 / 19$ & $16: 20 / 19$ & $11: 40 / 20$ \\
\hline CAM & $07: 30 / 15$ & $01: 10 / 16$ & $18: 40 / 16$ & $12: 40 / 17$ & $05: 10 / 18$ & 00:00/19 & $17: 30 / 19$ & $11: 30 / 20$ \\
\hline CEL & $07: 40 / 15$ & $01: 10 / 16$ & $18: 40 / 16$ & $12: 50 / 17$ & $06: 10 / 18$ & $00: 00 / 19$ & & \\
\hline DZIL & $07: 40 / 15$ & $01: 00 / 16$ & $18: 50 / 16$ & $12: 40 / 17$ & $05: 50 / 18$ & $23: 50 / 18$ & $16: 10 / 19$ & $11: 20 / 20$ \\
\hline RLAG & $07: 50 / 15$ & $01: 00 / 16$ & $18: 50 / 16$ & $12: 40 / 17$ & $06: 10 / 18$ & $23: 50 / 18$ & $16: 00 / 19$ & $11: 20 / 20$ \\
\hline CAN & $07: 50 / 15$ & $00: 50 / 16$ & 19:00/16 & $12: 20 / 17$ & $06: 20 / 18$ & $23: 40 / 18$ & & $11: 10 / 20$ \\
\hline $\mathrm{COZ}$ & $07: 50 / 15$ & $01: 00 / 16$ & 19:00/16 & $12: 30 / 17$ & & $23: 40 / 18$ & & $11: 10 / 20$ \\
\hline SKAA & $07: 50 / 15$ & 01:00/16 & $18: 50 / 16$ & $12: 30 / 17$ & $06: 40 / 18$ & $23: 50 / 18$ & $16: 40 / 19$ & $11: 10 / 20$ \\
\hline AXCA & $07: 50 / 15$ & 01:00/16 & 19:00/16 & $12: 30 / 17$ & $06: 10 / 18$ & $23: 50 / 18$ & & $11: 10 / 20$ \\
\hline
\end{tabular}

Local time (CST time - UTC-6); Dates: from January 15 to 20; PX shock wave peaks.

\subsubsection{Tide gauge}

The first tsunami waves recorded on the Mexican Pacific coast arrived around 06:26 on January 15, at the Huatulco station (Figure 5 and Table 2). Because of the morphology of the Mexican Pacific shoreline, the arrival of the first wave occurred between 06:26 and 08:00; only La Paz-Baja California, Mazatlán and Puerto Vallarta stations registered the first wave arrival after 09:00, and in Puerto Angel, Oaxaca, at 11:01. The maximum tsunami height recorded exceeded 
$2 \mathrm{~m}$ at the Ensenada and Manzanillo tide gauge stations, while at Zihuatanejo, Puerto Ángel, Huatulco and Salina Cruz stations maximum tsunami heights were more than $1 \mathrm{~m}$. These maximum heights were observed on January 16.

The records show the tsunami maximum height in Ensenada and Manzanillo, and the wave arrived in the morning (on January 15 at 08:18 and 11:56 hrs, respectively). At 6 stations (LPZ, LCAR, ZIH, PANG, SCRZ and PCHI) the wave arrived between January 16 and 17. Another important factor is that, of the 12 stations, 7 showed heights greater than $1 \mathrm{~m}$ (ENS, MAN, ZIH, ACA, PANG, HUA and SCRZ). Finally, the sea disturbance by the tsunami lasted until January 20, at the Ensenada, Zihuatanejo, Acapulco and Salina Cruz stations showing a decrease near to the $20^{\text {th }}$ of January.

Tide gauges also recorded disturbances in the Gulf of Mexico and the Mexican Caribbean. Sea disturbance was first observed in the Gulf of Mexico at the Tuxpan station, around 07:47, and the maximum height of the recorded wave was $0.437 \mathrm{~m}$ at the Veracruz station (Figure 5 and Table 2).

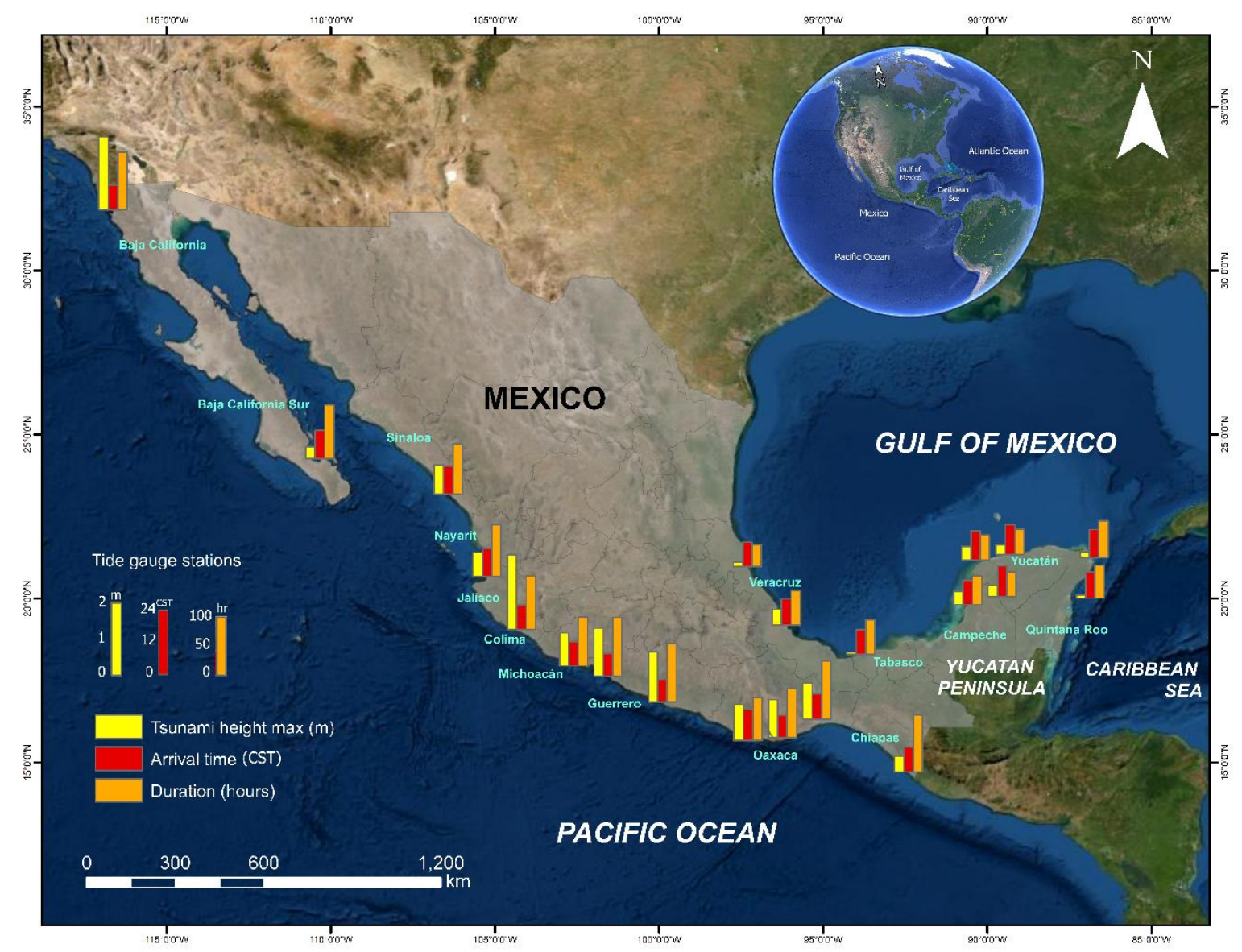

Figure 5. Tide gauge stations and tsunami parameters. Tsunami maximum heights - yellow bar; wave arrival time (24-hour - CST time, UTC+6) - red bar; and approximate time of recorded sea level disturbance - orange bar. Data source: National Tide Gauge Service (SMN). 
Table 2 Tide gauge stations and tsunami parameters.

\begin{tabular}{|c|c|c|c|c|}
\hline Station & Arrival time & $\begin{array}{c}\text { Tsunami height max } \\
\text { (m) }\end{array}$ & $\begin{array}{l}\text { Time tsunami height } \\
\text { max (time/day) }\end{array}$ & $\begin{array}{c}\text { Disturbance duration } \\
\text { (hrs) }\end{array}$ \\
\hline \multicolumn{5}{|l|}{ Pacific } \\
\hline ENS & $07: 29$ & 2.0177 & $08: 18 / 15$ & 109.36 \\
\hline LPZ & $09: 47$ & 0.334 & $07: 11 / 16$ & 102.01 \\
\hline MAZ & 09:50 & 0.809 & $21: 02 / 15$ & 95.08 \\
\hline PVAL & 09:39 & 0.678 & $21: 57 / 15$ & 99.18 \\
\hline MAN & $07: 37$ & 2.082 & $11: 56 / 15$ & 102.03 \\
\hline LCAR & 07:39 & 0.915 & $10: 13 / 16$ & 92.55 \\
\hline ZIH & $06: 46$ & 1.32 & 09:20/16 & 111.1 \\
\hline $\mathrm{ACA}$ & $06: 44$ & 1.395 & $20: 29 / 15$ & 111 \\
\hline PANG & $11: 01$ & 1.009 & $00: 45 / 16$ & 81.13 \\
\hline HUA & $06: 26$ & 1.056 & $23: 58 / 15$ & 93.18 \\
\hline SCRZ & 08:03 & 1.013 & $00: 44 / 16$ & 110.26 \\
\hline PCHI & $07: 56$ & 0.426 & $01: 52 / 17$ & 108.4 \\
\hline \multicolumn{5}{|c|}{ Caribbean } \\
\hline TUX & $07: 47$ & 0.134 & $17: 13 / 15$ & 42.23 \\
\hline VER & $08: 25$ & 0.437 & $17: 00 / 15$ & 65.11 \\
\hline SMAG & $07: 58$ & 0.058 & $19: 42 / 15$ & 65.49 \\
\hline CAM & $07: 49$ & 0.362 & $03: 16 / 16$ & 54.11 \\
\hline CEL & 11:05 & 0.319 & $02: 12 / 16$ & 46.28 \\
\hline SIS & $10: 14$ & 0.377 & $02: 14 / 16$ & 48.25 \\
\hline TEL & $10: 37$ & 0.272 & $03: 30 / 16$ & 48.09 \\
\hline IMUJ & $09: 17$ & 0.151 & $03: 33 / 16$ & 69.15 \\
\hline PMOR & $08: 23$ & 0.088 & $13: 26 / 17$ & 62.43 \\
\hline
\end{tabular}

The Gulf of Mexico tide gauge stations at Tuxpan, Veracruz, and Sánchez-Magallanes, show sea disturbances on January 15 at 07:47 hrs, 08:25 and 07:58, respectively. The maximum height in Tuxpan was $0.134 \mathrm{~m}$ at 17:13 hrs, in Veracruz 0.467m at 17:00 hrs, and in Sanchez-Magallanes 0.058m at 17:42 hrs. The duration of major sea disturbance occurred at the Isla Mujeres station (69.15 hours).

At the Caribbean Sea, initial changes in sea waves were observed at 07:49 at the Campeche station, at 11:05 at the Celestún station, at 10:14 at Sisal, in Telchac at 10:36, in Isla Mujeres at 09:17 and in Puerto Morelos at 08:23. On January 16 the maximum heights of 0.362m were observed in Campeche at 03:16 hrs, in Celestún 0.319m at 02:12 hrs, in Sisal $0.377 \mathrm{~m}$ at $02: 14 \mathrm{hrs}$, in Telchac $0.272 \mathrm{~m}$ at $03: 30 \mathrm{hrs}$, and in Isla Mujeres $0.151 \mathrm{~m}$ at 03:33 hrs, while in the Puerto Morelos station it was recorded on January 17 at 13:26 hrs and the wave height was $0.088 \mathrm{~m}$. 


\subsection{Tsunami Warning, social media, and people's response in Mexico?}

Tsunami warning bulletins are delivered by the Center of Tsunami Warning (CAT - Centro de Alerta de Tsunamis in Spanish, ascribed to the Mexican Navy (SEMAR). The first bulletin issued by CAT after the Hunga Tonga-Hunga Ha'apai volcano eruption on January 15, 2022, at 17:10 local time (central Mexico time 22:10 January 14), was on January 15, 2022, at 10:13 local time (16:27 UTC 0). The first advisory by CAT was that "no significant sea level changes were expected on the Mexican coasts. However, some currents might be observed on ports of the Pacific coast". The original source of the "earthquake" information was from the National Data Buoy Center (NOAA, 2022) and the US Tsunami Warning (NOAA/National Weather Service, 2022) (01:27 local time). Another bulletin was issued later by CAT at 17:30 local time in Mexico (23:30 UTC 0), addressed to all civil and military authorities. In this bulletin (number 005) by CAT a line indicates to disregard seismic data since it is a volcanic event. The update indicates that tide gauge data from ports show a decrease in elevation in all Mexican Pacific ports (Table 3), all indicate a height in the range of $0.1 \mathrm{~m}$ up to $0.3 \mathrm{~m}$, however the time of observations is not indicated. Here the suggestions are to "...take care of boats, population and activities at the ports on the coastal zone, due to potential strong currents at national ports. And to follow the instructions by local authorities from Civil Protection (Protección Civil)". The source of information for this bulletin is from the tide gauge SINAT system (Sistema Nacional de Trámites, Secretaría de Medio Ambiente y Recursos Naturales). Tsunami bulletins by CAT are given directly to the government authorities and anybody can read them in an app "Tsunami MX” (Secretaría de Marina - CAT, 2022).

The role of Civil Protection (CP) in Mexico is to organize and coordinate local government offices, people, actions and resources by municipalities; it is responsible for disaster relief, based on risk identification, availability of material and human resources, community preparedness and local response capacity. After the first bulletin by CAT, the Mexican CP published on its Twitter account on January 15 at 12:11 local time, the same information by CAT, that a volcanic eruption occurred by a submarine volcano near Tonga and that based on the event characteristics and location, "NO" significant sea level changes were expected on the Mexican Coast (Protección Civil México, 2022). Most of the advisories from Mexican authorities were issued on social media networks (as Facebook pages or twitter profiles), and some of them were published on Government's official websites. A database with the advisories given on social media sites and official websites from local governments and civil protection authorities is shown on Table 3.

All communications and bulletins were given on Twitter or Facebook by the state offices of Protección Civil in Jalisco, Colima, Michoacán, Guerrero, Chiapas, and Oaxaca, the latest also put online a report (Table 3). Only the CP from 
Colima and Guerrero explicitly indicate caution and to avoid going to the sea or near the sea until further notice. It is worth mentioning that the Oaxaca office of CP published on Twitter that “....it is recommended to ignore parameters of tsunamis generated by earthquake since it was a volcanic event" (Protección Civil Oax, 2022) (Figure 6).

\section{Advisories timeline: Mexican case}

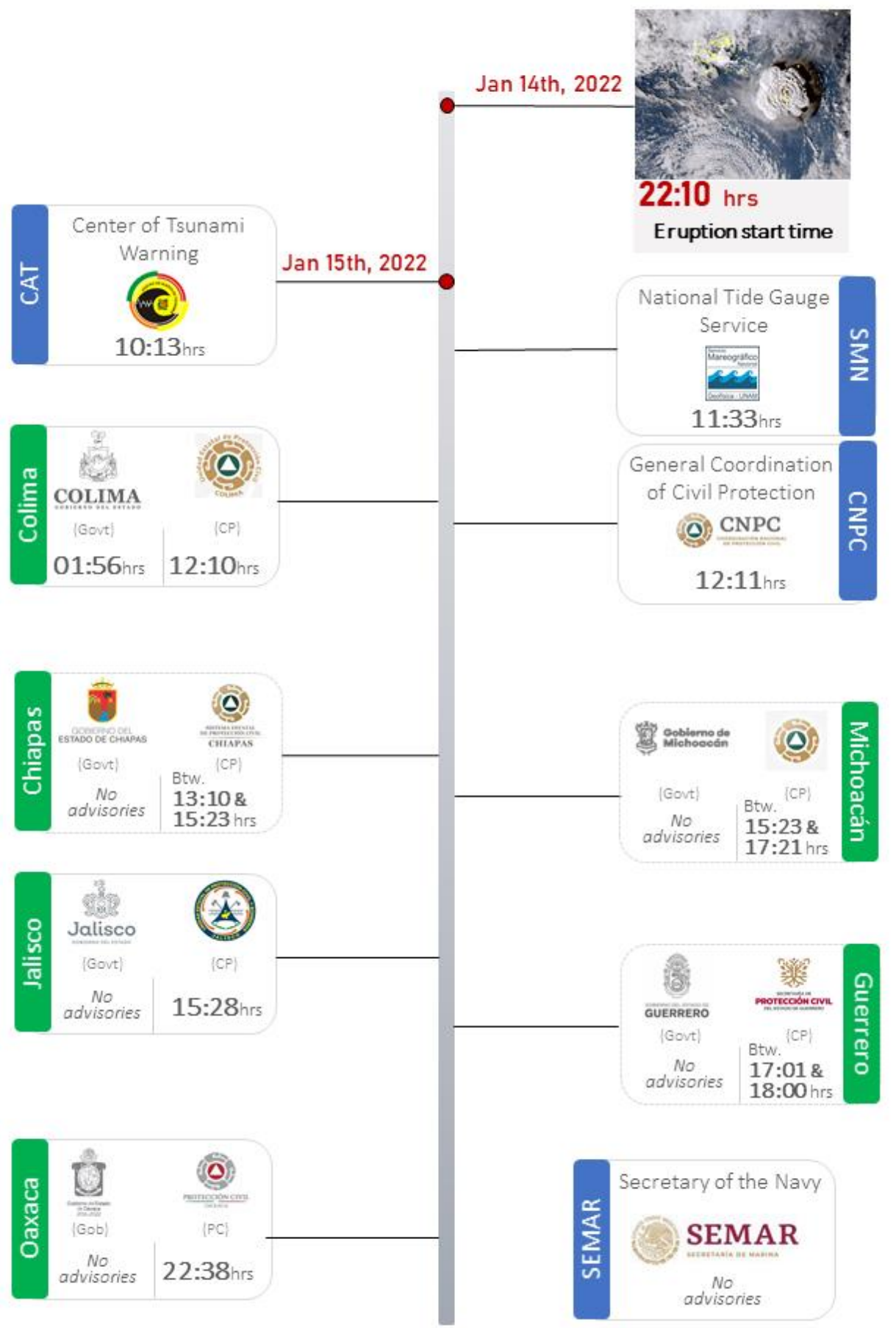


Ramirez-Herrera et al., Tsunami effects on the Coast of Mexico by the Hunga Tonga-Hunga Ha'apai volcano eruption

Figure 6 Timeline of Advisories dissemination time.Timeline of Advisories dissemination time by local governments (govt.), Local Civil Protection (CP), Secretary of the Navy, Mexico (SEMAR), the General Coordination of Civil Protection (CNPC), the National Tide Gauge Service (SMN) and the Center of Tsunami Warning (CAT). Dashed figures indicate that an advisory was given but the publication time is not clear (it was issued between a period of time indicated with the abbreviation "btw.").

Table 3 Tsunami warning advisories on social networks (Twitter, Facebook and Website) in Mexico.

\begin{tabular}{|c|c|c|c|}
\hline Institutions & Dissemination medium & $\begin{array}{c}\text { Issued time, CST } \\
\text { (January 15th) }\end{array}$ & Link \\
\hline \multirow{3}{*}{ Jalisco (govt.) } & Government website & No warnings/advisories & - \\
\hline & Facebook & No warnings/advisories & - \\
\hline & Twitter & No warnings/advisories & - \\
\hline \multirow[t]{3}{*}{ CP Jalisco } & Facebook & $15: 28$ & https://www.facebook.com/PCJalis \\
\hline & Twitter & $15: 28$ & co19/posts/4826040197461700 \\
\hline & & & $\begin{array}{l}\text { https://twitter.com/PCJalisco/status/ } \\
1482464763011637255 ? \mathrm{~s}=20\end{array}$ \\
\hline \multirow[t]{4}{*}{ Colima (govt.) } & Government website & Unknow & https://www.col.gob.mx/Portal/deta \\
\hline & Facebook & $13: 56$ & le_noticia/NDk3NjY= \\
\hline & Twitter & $13: 57$ & https://www.facebook.com/gobiern \\
\hline & & & ocolima/posts/4984934244905234 \\
\hline \multirow[t]{5}{*}{ CP Colima } & Facebook & $12: 10$ & https://twitter.com/gobiernocolima/ \\
\hline & Twitter & $12: 51$ & $\underline{\text { status } / 1482441852007575553 ? \mathrm{~s}=20}$ \\
\hline & & & https://www.facebook.com/pccolim \\
\hline & & & $\mathrm{a} /$ posts $/ 3204712863148927$ \\
\hline & & & $\begin{array}{l}\text { https://twitter.com/PC_Colima/statu } \\
\text { s/1482425328785969154?s=20 }\end{array}$ \\
\hline \multirow{4}{*}{$\begin{array}{l}\text { Michoacán } \\
\text { (govt.) }\end{array}$} & Government website & No warnings/advisories & - \\
\hline & Facebook & No warnings/advisories & - \\
\hline & Twitter & No warnings/advisories & - \\
\hline & Facebook & No warnings/advisories & \\
\hline \multirow[t]{2}{*}{ CP Michoacán } & Twitter & Unclear & $\underline{\text { https://twitter.com/CNPC_MX/statu }}$ \\
\hline & & & $\underline{\mathrm{s} / 1482463422390358022 ? \mathrm{~s}=20}$ \\
\hline \multirow{3}{*}{$\begin{array}{l}\text { Guerrero } \\
\text { (govt.) }\end{array}$} & Government website & No warnings/advisories & - \\
\hline & Facebook & No warnings/advisories & - \\
\hline & Twitter & No warnings/advisories & - \\
\hline & Facebook & $17: 50$ & https://www.facebook.com/SPCGro \\
\hline \multirow[t]{3}{*}{ CP Guerrero } & Twitter & Unclear & /posts/3077147755893518 \\
\hline & & & https://twitter.com/CNPC_MX/statu \\
\hline & & & $\underline{\mathrm{s} / 1482488013166886914 ? \mathrm{~s}=20}$ \\
\hline \multirow[t]{3}{*}{ Chiapas (govt.) } & Government website & No warnings/advisories & - \\
\hline & Facebook & No warnings/advisories & - \\
\hline & Twitter & No warnings/advisories & - \\
\hline \multirow[t]{5}{*}{ CP Chiapas } & Facebook & $15: 52$ & https://www.facebook.com/pcivilch \\
\hline & Twitter & Unclear & iapas.chiapas/posts/4922935257727 \\
\hline & & & $\underline{602}$ \\
\hline & & & $\underline{\text { https://twitter.com/CNPC MX/statu }}$ \\
\hline & & & $\mathrm{s} / 1482430093150633984 ? \mathrm{~s}=20$ \\
\hline \multirow[t]{3}{*}{ Oaxaca (govt.) } & Government website & No warnings/advisories & - \\
\hline & Facebook & No warnings/advisories & - \\
\hline & Twitter & No warnings/advisories & - \\
\hline
\end{tabular}




\begin{tabular}{|c|c|c|c|}
\hline CP Oaxaca & $\begin{array}{l}\text { Facebook } \\
\text { Twitter }\end{array}$ & $\begin{array}{l}\text { No warnings/advisories } \\
22: 38\end{array}$ & $\begin{array}{l}- \\
\underline{\text { https://twitter.com/CEPCO_GobOa }} \\
\underline{\underline{2} \text { /status/1482572916143411206?s= }}\end{array}$ \\
\hline $\begin{array}{l}\text { Secretary of } \\
\text { the Navy, } \\
\text { Mexico } \\
\text { (SEMAR) }\end{array}$ & $\begin{array}{l}\text { Official website Facebook } \\
\text { Twitter }\end{array}$ & $\begin{array}{l}\text { No warnings/advisories } \\
\text { No warnings/advisories } \\
\text { No warnings/advisories }\end{array}$ & 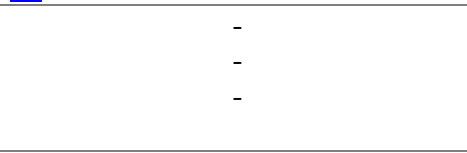 \\
\hline $\begin{array}{l}\text { General } \\
\text { Coordination } \\
\text { of Civil } \\
\text { Protection } \\
\text { (CNPC) }\end{array}$ & $\begin{array}{l}\text { Official website Facebook } \\
\text { Twitter }\end{array}$ & $\begin{array}{l}\text { No warnings/advisories } \\
12: 20 \\
12: 11\end{array}$ & $\begin{array}{l}- \\
\text { https://www.facebook.com/CNPCm } \\
\frac{\text { x/posts/832016017648286 }}{\text { https://twitter.com/CNPC_MX/statu }} \\
\underline{\text { s/1482415110207545345?s=20 }}\end{array}$ \\
\hline $\begin{array}{l}\text { National Tide } \\
\text { Gauge Service } \\
\quad \text { (SMN) }\end{array}$ & $\begin{array}{l}\text { Official website } \\
\text { Twitter }\end{array}$ & $\begin{array}{l}11: 33 \\
11: 33\end{array}$ & $\begin{array}{l}\text { http://www.mareografico.unam.mx/ } \\
\text { portal/index.php?page=Estaciones } \\
\text { https://twitter.com/SMareograficoN } \\
\underline{\text { /status/1482405602135580680?s }=2} \\
\underline{0}\end{array}$ \\
\hline $\begin{array}{l}\text { Center of } \\
\text { Tsunami } \\
\text { Warning } \\
\text { (CAT) }\end{array}$ & Official website & $11: 13$ & $\begin{array}{l}\text { https://digaohm.semar.gob.mx/cat/b } \\
\text { oletinesCAT.html }\end{array}$ \\
\hline
\end{tabular}

\subsubsection{How did people learn and react to this tsunami in Mexico?}

Media and social media (mainly Twitter and Facebook) reported the Hunga Tonga-Hunga Ha'apai volcano eruption and tsunami as well as the potential implications in Mexico. Most Media, social media, News on TV and online repeated what the CAT reported in their bulletins; however, some reports unfortunately minimize the hazard by comparing the tsunami heights on the Pacific coast of Mexico with "high tides", "high sea level", and "sea waves" (Tapia, 2022; Noticieros Televisa, 2022; etc.). Even the Civil Protection from Baja California, indicated in its Facebook site that ...” there were no threats to the Baja coast because the event occurred far away from this coast" (Protección Civil Baja California, 2022). However, on the Manzanillo coast, tide gauges registered sea level as high as $2 \mathrm{~m}$ above normal, also in Ensenada, Baja California (Figure 5).

Overall, in Mexico tsunami evacuation warning was not delivered, instead a tsunami warning indicated caution due to higher sea waves and strong currents by CP. Colima's CP warned people of "no normal" sea situation and clearly advised them to stay away from the sea (Olvera, 2022).

Some people went to the coast and shared videos on their personal Twitter and Facebook accounts that showed the effects on the coast at the time. In Rosarito, Baja California, despite the strong waves and tsunami alert, surfers headed to the sea (Velazquez, 2022). On the Manzanillo, Colima coast, the sea retreated, and fishes were observed onshore by January 15 at 13:12 local time (Diario Vigía, 2022). Also, strong currents hit the port of Manzanillo with no casualties 
since people were alerted of a potential tsunami (Radar Sonora, 2022). A video taken in Zihuatanejo at the time of the tsunami arrival about 06:46, strong currents were observed by locals (Noticieros Televisa, 2022a).

By 17:26 local time Civil Protection in Huatulco had no tsunami warning for locals in Huatulco, Oaxaca, according to the local Firemen (Hamblet Torrija, personal communication) and a video interview, in which the head of the local Civil Protection indicated that the sea was calm and there was no tsunami threat, encouraging tourist to stay calm (Video shared by Fireman Hamblet Torrija). However, earlier on, strong currents hit the Santa Cruz dock in Oaxaca and a boat sank at about 17:30 local time (Video shared by Fireman Hamblet Torrija).

\section{Discussion and conclusion}

Although far field tsunamis produced by volcanic eruptions occur seldom, the Hunga Tonga-Hunga Ha'apai volcano event reminds us of the importance of submarine volcanoes monitoring and inclusion of this type of events in the tsunami early warning systems. It is the very first eruption-generated tsunami to trigger the Pacific Ocean alert systems that have been in place since 1949.

This tsunami reached the coast of most countries around the Pacific Ocean basin, some of them had a rapid tsunami warning (e.g. Japan, US and Chile), but some didn't such as Peru where two people died and a devastating oil spill occurred on coastal protected areas, where the fauna and vegetation have been badly damaged (DW Español, 2022).

Our results summarized here the effects of the tsunami triggered by the volcano explosion on the coast of Mexico. Direct effects of the tsunami were observed along the Pacific coast of Mexico, and the largest tsunami heights ( $2 \mathrm{~m}$ ) were measured by tide gauges on the Manzanillo-Colima and Ensenada-Baja California coast, where strong currents were also observed. Although no damage was reported, the Santa Cruz dock at the Huatulco-Oaxaca coast had a boat sunk.

The effects by the Hunga Tonga-Hunga Ha'apai volcano explosion went beyond the eruption and tsunami expected locally, and the shock wave produced by the explosion caused sea perturbations that went beyond the Pacific Ocean basin, reaching the coasts on the Mexican Caribbean Sea and Gulf of Mexico. Meteorological stations reported several peaks measured on barometers and sea perturbations at tide gauges on the Caribbean Sea and Gulf of Mexico that lasted from January 15 to the 20 . No casualties were reported but no tsunami evacuation warning was activated on these coasts in Mexico. 
Around the globe the news of the volcano eruption spread quickly, and there was a rapid response by the Pacific Tsunami Warning Center (PTWC) and NOAA, IOC, ITIC, and many other scientific organizations in the world, e.g. US, Japan, Australia, and New Zealand, to name some of them. In Mexico, CAT followed initially information provided by the PTWC (Bulletin 005, 1432 UTC SAT JAN 15 2022) and NOAA, since this was an extraordinary tsunami event not produced by an earthquake, adjustments had to be made to understand the threat at several coasts around the Pacific Ocean. CAT in Mexico produces the tsunami warning bulletin, but is not responsible but reaching out communities, and this is where the Civil Protection of Mexico acts to warn and inform people of potential tsunami threats and the actions that people should take.

Although it is not our aim to assess the response by CAT nor by CP Mexico, tsunami warning in Mexico, with one exception, directed people to take caution, but did not clearly state that people must stay away from the shore. The vast majority of tsunami warnings reached communities via social media such as Twitter and Facebook. We wonder if this is the most effective way to warn coastal communities in Mexico. Fortunately, no casualties, apart from damage to boats on ports and ducks were reported.

Many lessons can be learned from this event, both scientific and social. It was devastating for the people of Tonga, a combination of volcanic eruption, ashes and a tsunami on Tonga people, though their quick reaction and tsunami warning helped in decreasing human losses, at a time when most communications (internet, TV) failed, the radio continued warning people of the tsunami threat (Testimony by Tevita Tai Fukofuka) (Fukofuka, 2022). The people of Tonga have shown that they are resilient, despite these cascading series of events in the middle of a pandemic by COVID-19. At the moment we are writing this manuscript, Tonga people are still working to recover and rise back.

We suggest that although no casualties were reported in Mexico, tsunami warning by far field tsunamis and those triggered by volcanic eruptions should be improved to reach out people and coastal communities timely and explain the associated hazards, such as strong currents, on the coast. People should be warned to stay away from the sea till further notice is given on none further hazard. We also suggest that international efforts must be made to monitor submarine volcanoes and collaborate with the local scientists and organizations, such as Tonga, working by their side in such an effort.

\section{Acknowledgments}

We thank Hamblet Torija and Nésctor Corona for sharing videos of the Tonga tsunami at the Mexican coastal zone. Thanks to José A. Hernández R., Librarian at Institute of Geography (UNAM), for sharing newspaper information on 
the event. Thanks to scientists from all over the world, who quickly published information on social media. Oswaldo Coca thanks the UNAM-CONAcyT doctoral scholarship and Victor Vargas the UNAM-CONAcyT master scholarship.

\section{Supplementary material}

Table S1 Time between shock wave peaks $(\mathrm{P})$.

Table S2 Links to information published on social media (Twitter and YouTube).

\section{References}

Bryant, T. (2001). Tsunamis. Cambridge University Press.

CNN (2022, January 15). Perú: Oleaje anómalo afectó al litoral peruano a pesar que la Armada había descartado un tsunami en las costas del país. CNN Chile. https://www.cnnchile.com/mundo/peru-oleaje-litoral-marina-descartotsunami-costas_20220115/

Cronin, S. J., Brenna, M., Smith, I. E. M., Barker, S. J., Tost, M., Ford, M., Tonga'onevai, S., Kula, T., \& Vaiomounga, R. (2017). New volcanic island unveils explosive past. Eos, 98, https://doi.org/10.1029/2017EO076589

Cronin, S. J. (2022). Why the volcanic eruption in Tonga was so violent, and what to expect next. The Conversation. From https://theconversation.com/why-the-volcanic-eruption-in-tonga-was-so-violent-and-what-to-expect-next$\underline{175035}$

Choi, B.H., Pelinovsky, E., Kim, K.O., \& Lee, J.S., (2003). Simulation of the trans-oceanic tsunami propagation due to the 1983 Krakatau volcanic eruption. Natural Hazards and Earth System Sciences, vol. 3, No. $5,321-332$.

Diario Vigía. (2022, January 15). Video tomado Hoy por la mañana, el mar se está recorriendo y muchos peces se quedan a la orilla, esto en la zona de \#Salahua. [Video - Facebook Watch]. Facebook. https://fb.watch/ayT1VDUa0E/

DW Español. (2022, January 18). Gobierno de Perú pide explicaciones a Marina de Guerra. [Video]. YouTube https://youtu.be/_gHV00kOLAQ

Fukofuka, T. T. [Tevita Tai Fukofuka] (2022, January 21). Wrote this Sunday 16 Jan 2022 the day after the explosions. It's long but it's for those who were fortunate enough not to be in the country and want a glimpse of what happened... [Post]. Facebook. https://m.facebook.com/story.php?story_fbid=7206228949417857\&id=100000924717160

Government of Tonga (2022). First Official Update Following the Volcanic Eruption. Media Release 18th January, 2022.

Klein, L. (2022). Volcano eruption in Tonga was a once-in-a-millennium event. New Scientist, 17 January 2022.

Maeno, F., \& Imamura, F. (2011). Tsunami generation by a rapid entrance of pyroclastic flow into the sea during the 1883 Krakatau eruption, Indonesia. J. Geophys. Res., 116, B09205, doi:10.1029/2011JB008253

Nagai, K., Muhari, A., Pakoksung, K., Watanabe, M., Suppasri, A., Arikawa, T., \& Imamura, F., (2021). Consideration of submarine landslide induced by 2018 Sulawesi earthquake and tsunami within Palu Bay. Coastal Engineering Journal, 63:4, 446-466, DOI: 10.1080/21664250.2021.1933749

National Oceanic and Atmospheric Administration's - NOAA. (2022). National Data Buoy Center. https://www.ndbc.noaa.gov/ 
National Oceanic and Atmospheric Administration's - NOAA/National Weather Service (2022). U.S. Tsunami Warning System. https://www.tsunami.gov/

National Tsunami Warning Center (NTWC). (2022). ITIC Tsunami Bulletin Board Tsunami Information Statement Number 1, NWS National Tsunami Warning Center Palmer AK, 300 AM PST Sat Jan 15 2022, National Oceanic and Atmospheric Administration.

Nomanbhoy, N., \& Satake, K. (1995). Generation mechanism of tsunamis from the 1883 Krakatau Eruption. Geophysical Research Letters, 22- 4, 509-512, https://doi.org/10.1029/94GL03219.

Noticieros Televisa. (2022, January 15). Aumenta nivel del mar en México por erupción en Tonga - Sábados de Foro. [Video]. YouTube. https://www.youtube.com/watch?v=5W3-LzcibiY

Noticieros Televisa. (2022a, January 15). Guerrero resiente efectos de erupción del volcán en Tonga - Las Noticias. [Video]. YouTube. https://www.youtube.com/watch?v=ZriTf-nKEA0

Olvera, E. (2022, January 15). Tonga: Colima alerta por daños en costa tras Tsunami por erupción de volcán. Informador.Mx. https://www.informador.mx/mexico/TONGA-Colima-alerta-por-danos-en-costa-tras-Tsunami-porerupcion-de-volcan-20220115-0070.html

Pacific Tsunami Warning Center (PTWC). (2022). Tsunami Information statement 001-005, Sat Jan 15 2022, ITIC Tsunami Bulletin Board. Intergovernmental Oceanographic Commission, UNESCO.

Pararas-Carayannis, G. (1992). The tsunami generated from the eruption of the volcano of Santorin in the Bronze Age. Natural Hazards, 5, 115-123. doi: 10.1007/BF00127000.

Pelinovsky E., Choi, B., Stromkov, A., Didenkulova, I., \& Kim, H., (2005). Analysis of tide-gauge records of the 1883 Krakatau tsunami. In K. Satake (Ed.) Tsunamis: case studies and recent developments. Springer, 57-78.

Protección Civil Baja California. (2022, January 15). AVISO IMPORTANTE. Derivado de la Alerta de Tsunami emitida esta mañana por la NOAA se informa que: Este fenómeno no representa un riesgo para las Costas de Baja California ya que el fenómeno de origen se encuentra muy lejos de nuestro territorio. No es necesaria ninguna $\begin{array}{llll}\text { evacuación. } & \text { [Publicación } & \text { de } & \text { Facebook. }\end{array}$ https://www.facebook.com/login/?next=https\%3A\%2F\%2Fwww.facebook.com\%2Fproteccivilbc\%2Fposts\%2F6892 $\underline{977410775863}$

Protección Civil México [@CNPC_MX]. (2022, January 15). Debido a la erupción de un \#volcán submarino cercano a \#Tonga en el \#Pacífico, el Centro de Alerta de \#Tsunamis de_@SEMAR_mx, informa que: Con base en las características y ubicación del evento, NO se esperan variaciones significativas en el nivel del mar en costas de \#México. [Tweet]. Twitter. https://twitter.com/CNPC_MX/status/1482415110207545345?s=20

Protección Civil Oax [@CEPCO_GobOax]. (2022, January 15). La \#CEPCO informa: debido al evento generado por la erupción del volcán en la isla de Toga, se recomienda ignorar parámetros de tsunamis generados por sismo ya que fue un evento volcánico. El monitoreo se continúa realizando con ayuda de las estaciones mareográficas,.. [Attached image]. [Tweet]. Twitter. https://twitter.com/CEPCO_GobOax/status/1482572916143411206?s=20

Radar Sonara. (2022, January 15). \#NACIONAL Así en Manzanillo, Colima, con efectos de la erupción del volcán submarino en la isla de Tonga, Japón, al sureste del Océano. [Video - Facebook Watch]. Facebook. https://www.facebook.com/RadarSonoraNoticias/videos/251866520355818/?extid=NS-UNK-UNK-UNKIOS_GK0T-GK1C

Secretaría de Marina - CAT. (2022). Último Boletín, Centro de Alerta de Tsunamis. https://digaohm.semar.gob.mx/cat/centroAlertasTsunamis.html

Servicio Mareográfico Nacional - SMN (2022). Universidad Nacional Autónoma de México, Instituto de Geofísica, México.http://www.mareografico.unam.mx 
Servicio Meteorológico Nacional (SMN) - CONAGUA. (2022). Secretaría de Medio Ambiente y Recursos Naturales, Gobierno de México, México.https://smn.conagua.gob.mx/es/

Simkin, T., \& Fiske, R.S., (1983). Krakatau 1883 - the volcanic eruption and its effects. Smithsonian Institution Press, Washington, D.C.

Taj, M. (2022, January 21). Oil Spill Triggered by Tsunami Devastates Coast of Peru. The New York Times. https://www.nytimes.com/2022/01/21/world/americas/peru-oil-spill-tonga-tsunami.html

Tapia, M. (2022, January 15). Descartan en Baja California afectación por alerta de tsunami en EU. El Sol de México. https://www.elsoldemexico.com.mx/republica/sociedad/baja-california-descartan-afectacion-por-alerta-de-tsunamien-eu-7735212.html

USGS (2022). M 5.8 Volcanic Eruption - 68 km NNW of Nuku'alofa, Tonga. USGS, Earthquake Hazard Program, Latest Earthquakes, https://earthquake.usgs.gov/earthquakes/eventpage/us7000gc8r/executive

Velázquez, L. [Lidy Velázquez Vlogs]. (2022, January 15). Grandes olas en Rosarito por el tsunami Tonga Surfistas salen. [Video]. YouTube. https://youtu.be/V5YtRRNHz_8

Watkins A.B. (2022). Tonga tide gauge before it stopped reporting. January 15, 2022.

https://twitter.com/windjunky/status/1482335120401248256?s=20

Yokoyama, I., (1981). A geophysical interpretation of the 1883 Krakatau eruption. Journal Volcanology and Geothermal Research, vol. 9, 359-378. 


\section{LIST OF FIGURES}

\section{FIGURES}

Figure 1. Hunga-Tonga-Hunga Ha'apai volcano tectonic setting.

Figure 2. National Tide Gauge Service (SMN) and Automatic Weather Stations (EMA) stations on the Mexican coast.Automatic Weather Stations "EMA" - orange points, source: SMN-CONAGUA (2022), and tide gauge stations from the National Tide Gauge Service "SMN" - green points (SMN, 2022). EMA stations: PLOPZ (Presa López Zamora), OBI (Obispo), RTOM (Río Tomatlán), MAN (Manzanillo), PET (Petacalco), ZIH (Zihuatanejo), EVEL (El Veladero), PANG (Puerto Ángel), TAP (Tapachula), MAZL (Montes Azules), AXCA (Arrecife Xcalak), SKAA (Sian Kaan), COZ (Cozumel), CAN (Cancún), RLAG (Río Lagartos), DZIL (Dzilam), CEL (Celestún), CAM (Campeche), CDCAR (Ciudad del Carmen), LCAN (La Cangrejera), ALV (Alvarado) y TUX (Tuxpan). The tide gauge stations: ENS (Ensenada), LPZ (La Paz), MAZ (Mazatlán), PVAL (Puerto Vallarta), MAN (Manzanillo), LCAR (Lázaro Cárdenas), ZIH (Zihuatanejo), ACA (Acapulco), HUA (Huatulco), PANG (Puerto Ángel), PCHI (Puerto Chiapas), PMOR (Puerto Morelos), IMUJ (Isla Mujeres), TEL (Telchac), SIS (Sisal), CEL (Celestún), CAM (Campeche), SMAG (Sánchez _ Magallanes), VER (Veracruz) y TUX (Tuxpan). Inserts show the average distance between the Hunga-Tonga-Hunga-Ha'apai Volcano and Mexico. Data source: CONAGUA and SMN.

Figure 3. Shock waves recorded at the Mexican Pacific coast. Graphs show shock wave peaks generated by the Hunga-Tonga-Hunga-Ha'apai Volcano explosion (8 peaks). The image also shows examples of the time of recording (time and day - CST time) of the wave peaks (red letters) and the time between the recording of each wave (blue letters). Pacific stations. Source: SMN-CONAGUA (2022).

Figure 4. Shock wave peaks for the Gulf of Mexico and Mexican Caribbean Sea. Graphs show shock wave peaks generated by the Hunga-Tonga-Hunga-Ha'apai Volcano explosion ( 8 peaks). The image also shows examples of the time of recording (time and day - CST time) of the wave peaks (red letters) and the time between the recording of each wave (blue letters). Gulf of Mexico and Mexican Caribbean stations. Source: SMNCONAGUA (.2022) 
Figure 5. Tide gauge stations and tsunami parameters. Tsunami maximum heights - yellow bar; wave arrival time (24-hour - CST time, UTC+6) - red bar; and approximate time of recorded sea level disturbance - orange bar. Data source: National Tide gauge Service (SMN).

Figure 6 Timeline of Advisories dissemination time.Timeline of Advisories dissemination time by local governments (govt.), Local Civil Protection (CP), Secretary of the Navy, Mexico (SEMAR), the General Coordination of Civil Protection (CNPC), the National Tide Gauge Service (SMN) and the Center of Tsunami Warning (CAT). Dashed figures indicate that an advisory was given but the publication time is not clear (it was issued between a period of time indicated with the abbreviation "btw.").

\section{LIST OF TABLES}

Table 1 Weather stations, shock wave arrival, and peak parameters.

Table 2 Tide gauge stations and tsunami parameters.

Table 3 Tsunami warning advisories on social networks (Twitter, Facebook and Website) in Mexico.

\section{SUPPLEMENTARY MATERIAL}

Table S1 Time between shock wave peaks (P).

Table S2 Links to information published on social media (Twitter and YouTube). 


\section{SUPPLEMENTARY MATERIAL}

Table 1 Time between shock wave peaks $(\mathrm{P})$.

\begin{tabular}{|c|c|c|c|c|c|c|c|c|}
\hline Station & $\begin{array}{l}\text { Time } \\
\text { between } \\
\text { P1 and } \\
\text { P2 }\end{array}$ & $\begin{array}{l}\text { Time } \\
\text { between } \\
\text { P2 and } \\
\text { P3 }\end{array}$ & $\begin{array}{l}\text { Time } \\
\text { between } \\
\text { P3 and } \\
\text { P4 }\end{array}$ & $\begin{array}{l}\text { Time } \\
\text { between } \\
\text { P4 and } \\
\text { P5 }\end{array}$ & $\begin{array}{l}\text { Time } \\
\text { between } \\
\text { P5 and } \\
\text { P6 }\end{array}$ & $\begin{array}{l}\text { Time } \\
\text { between } \\
\text { P6 and } \\
\text { P7 }\end{array}$ & $\begin{array}{l}\text { Time } \\
\text { between } \\
\text { P7 and } \\
\text { P8 }\end{array}$ & Region \\
\hline PLOPZ & 21 & 13.4 & 22.1 & & & & & \multirow{10}{*}{ ڤ્. } \\
\hline OBI & 20.2 & 16 & 21.5 & 14.2 & 20.4 & & & \\
\hline RTOM & 20.2 & 16.1 & & & & & & \\
\hline MAN & 20.2 & 16 & 20.2 & 14.1 & 21 & & & \\
\hline PET & 20.1 & 16.2 & 20 & 14.3 & 20.4 & 15.3 & & \\
\hline ZIH & 20.1 & 16.3 & 19.5 & 14.4 & 21.3 & 15.3 & & \\
\hline EVEL & 20 & 16.3 & 19.5 & 14.5 & 21.1 & 15.5 & 19.3 & \\
\hline PANG & 19.3 & 17.2 & 19.1 & 15.5 & 19.3 & 16.3 & 18.5 & \\
\hline TAP & 19.1 & 18 & 18.4 & 16 & 19 & 17.2 & 18 & \\
\hline MAZL & 18.1 & 18.4 & 18 & & & 17.3 & 17.5 & \\
\hline TUX & 18.5 & 16 & 19.2 & 15 & 20.2 & & & \multirow{13}{*}{ 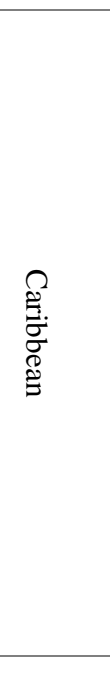 } \\
\hline ALV & 18.4 & 16.3 & 18.5 & & & & & \\
\hline LCAN & 18.3 & 16.4 & 18.5 & & & 16.5 & 18.3 & \\
\hline CDCAR & 18 & 17.1 & 18.2 & 16.4 & 18.5 & 16.1 & 19 & \\
\hline CAM & 17.4 & 17.3 & 18.2 & 16.3 & 18.5 & 17.3 & 18 & \\
\hline CEL & 17.3 & 17.3 & 18.1 & 17.2 & 17.5 & & & \\
\hline DZIL & 17.2 & 17.5 & 17.5 & 17.1 & 18 & 16.2 & 19.1 & \\
\hline RLAG & 17.1 & 17.5 & 17.5 & 17.3 & 17.4 & 16.1 & 19.2 & \\
\hline CAN & 17 & 18.1 & 17.2 & 18 & 17.2 & & & \\
\hline $\mathrm{COZ}$ & 17.1 & 18 & 17.3 & & & & & \\
\hline SKAA & 17.1 & 17.5 & 17.4 & 18.1 & 17.3 & 16.5 & 18.3 & \\
\hline AXCA & 17.1 & 18 & 17.3 & 17.4 & 17.4 & & & \\
\hline Average & 19 & 17 & 19 & 16 & 19 & 16 & 19 & \\
\hline
\end{tabular}

Data in hours. 
Table 2 Links to information published on social networks (Twitter and YouTube).

\begin{tabular}{|c|c|c|c|}
\hline \multicolumn{4}{|c|}{ Tsunami generated from today volcanic \#eruption (explosion) off Nuku'alofa, Tonga - effects in Mexico (?) } \\
\hline Data & Source & Information type & Location \\
\hline $\begin{array}{l}\text { Large eruption near } \\
\text { Tonga }\end{array}$ & $\begin{array}{l}\text { https://twitter.com/NWSHonolulu/status/14822 } \\
\underline{55559072096256 ? \mathrm{~s}=20}\end{array}$ & video & Tonga \\
\hline Zihuatanejo first effects & $\begin{array}{l}\text { https://twitter.com/TeresaRamirezH/status/1482 } \\
\text { 410890330877954?s=20 }\end{array}$ & Tidal gauge graph & Zihuatanejo \\
\hline $\begin{array}{l}\text { Oaxaca and Chiapas } \\
\text { first effects }\end{array}$ & $\begin{array}{l}\text { https://twitter.com/TeresaRamirezH/status/1482 } \\
\underline{413667123703813 ? \mathrm{~s}=20}\end{array}$ & Tidal gauge graph & $\begin{array}{l}\text { Huatulco and Pto } \\
\text { Madero }\end{array}$ \\
\hline Michoacan first effects & $\begin{array}{l}\text { https://twitter.com/TeresaRamirezH/status/1482 } \\
\underline{409466410713089 ? \mathrm{~s}=20}\end{array}$ & Tidal gauge graph & Lazaro Cardenas \\
\hline Colima first effects & $\begin{array}{l}\text { https://twitter.com/TeresaRamirezH/status/1482 } \\
\underline{408030713135111 ? \mathrm{~s}=20}\end{array}$ & Tidal gauge graph & Manzanillo \\
\hline SMN Report & $\begin{array}{l}\frac{\text { http://www.mareografico.unam.mx/portal/docu/ }}{\text { Pdfs/2022_01_15_REPORTE_PRELIMINAR }} \\
\underline{\text { TSUNAMI_TONGA.pdf }}\end{array}$ & Report & $\begin{array}{l}\text { *El tsunami } \\
\text { continuó después } \\
\text { de este reporte }\end{array}$ \\
\hline First model & $\begin{array}{l}\underline{\text { https://twitter.com/TeresaRamirezH/status/1482 }} \\
\underline{526027301761025 ? \mathrm{~s}=20}\end{array}$ & Video & Mexico \\
\hline $\begin{array}{l}\text { Múltiples PTWC } \\
\text { TSUNAMI THREAT } \\
\text { MESSAGE }\end{array}$ & & Emails & $\begin{array}{l}\text { Mexico and all the } \\
\text { world }\end{array}$ \\
\hline $\begin{array}{l}\text { Equivalent energy } \\
\text { released in the form of } \\
\text { waves is estimated at } \mathrm{M} \\
5.8\end{array}$ & $\begin{array}{l}\text { https://earthquake.usgs.gov/earthquakes/eventp } \\
\text { age/us7000gc8r/executive } \\
\text { https://www.facebook.com/nextquake/posts/37 } \\
40854419472179\end{array}$ & Report & $\begin{array}{l}\text { Mundo } \\
\text { (característica } \\
\text { evento) }\end{array}$ \\
\hline $\begin{array}{l}\text { Countries with tsunami } \\
\text { alert }\end{array}$ & $\frac{\text { https://twitter.com/andressitto21/status/148247 }}{\text { 0897688666115?t=DNpVSZUQNteHnx05wae }}$ & Image & Mundo \\
\hline $\begin{array}{l}\text { Effects in Manzanillo } \\
\text { and Colima }\end{array}$ & $\begin{array}{l}\underline{\text { https://twitter.com/SkyAlertMx/status/1482462 }} \\
\underline{375978618883 ? \mathrm{~s}=08}\end{array}$ & Video & Manzanillo \\
\hline $\begin{array}{l}\text { Countries with tsunami } \\
\text { alert }\end{array}$ & $\begin{array}{l}\text { https://twitter.com/Eliza_MartinezF/status/1482 } \\
\underline{\text { f12007198920705?t=TB0cgCkcnZ- }} \\
\underline{\text { fII2_HRojRw\&s=08 }}\end{array}$ & Image & Mundo \\
\hline Data & $\begin{array}{l}\underline{\text { https://twitter.com/IsaacRodrgz/status/1482453 }} \\
\underline{\text { f17310861317?t=Q2gSU8Ejm7e71PBcIw5BSg }}\end{array}$ & Tidal gauge graph & $\begin{array}{l}\text { Ensenada and } \\
\text { Manzanillo }\end{array}$ \\
\hline $\begin{array}{l}\text { First post-tsunami } \\
\text { images }\end{array}$ & $\begin{array}{l}\underline{\text { https://twitter.com/JoLatuSanft/status/1482524 }} \\
\underline{\text { L97603727361?t=wIyhhagjMD63n2j2D3m- }} \\
\underline{\text { w\&s }=08}\end{array}$ & Photos & $\begin{array}{l}\text { Islas Pangai, } \\
\text { Haapai }\end{array}$ \\
\hline
\end{tabular}


Ramirez-Herrera et al., Tsunami effects on the Coast of Mexico by the Hunga Tonga-Hunga Ha'apai volcano eruption

\begin{tabular}{|c|c|c|c|}
\hline $\begin{array}{l}\text { First effects of the } \\
\text { tsunami in Tonga }\end{array}$ & $\begin{array}{l}\text { https://twitter.com/chematierra/status/14822323 } \\
\underline{42613737473 ? \mathrm{t}=\mathrm{ySLO7Ac0tlU-pp0FEW78-}} \\
\underline{\mathrm{w} \& \mathrm{~s}=08}\end{array}$ & Video & Tonga \\
\hline Data & $\begin{array}{l}\frac{\text { https://twitter.com/SMareograficoN/status/1482 }}{\text { 406831502905344?t=HUznzLR75ZiykpOvTM }} \\
\text { p1gQ\&s=08 }\end{array}$ & Tidal gauge graph & Manzanillo \\
\hline $\begin{array}{l}\text { Wave shock across the } \\
\text { Pacific }\end{array}$ & $\begin{array}{l}\frac{\text { https://twitter.com/_FernandoNeyra/status/1482 }}{\underline{\text { 485731717091328?t=CvpXcSGM6MTRdcku }}} \\
\underline{\text { Mk2gdg\&s }=08}\end{array}$ & GIF & World \\
\hline $\begin{array}{l}\text { Scheme tsunami by } \\
\text { volcano }\end{array}$ & $\begin{array}{l}\underline{\text { https://twitter.com/treintonarocket/status/14825 }} \\
\underline{\text { 08649104916483?t=C3KuFlY8FfxHXWyh10s }} \\
\underline{\text { YIw\&s }=08}\end{array}$ & Image & \\
\hline Timelap Mogareeka & $\begin{array}{l}\underline{\text { https://twitter.com/LouisMoresi/status/1482455 }} \\
\underline{\text { 240104640512?t=VgzEhIjVagzxh64rnw2hkw }} \\
\underline{\& \mathrm{~s}=08}\end{array}$ & Video & Mogareeka \\
\hline $\begin{array}{l}\text { Event characteristics } \\
\text { (magma composition) }\end{array}$ & $\begin{array}{l}\underline{\text { https://twitter.com/ita_dc/status/148233181037 }} \\
\underline{8010625 ? \mathrm{~s}=20}\end{array}$ & $\begin{array}{l}\text { Post on social } \\
\text { network }\end{array}$ & Tonga \\
\hline $\begin{array}{l}\text { Modelo de onda de } \\
\text { choque de la erupción }\end{array}$ & $\begin{array}{l}\text { https://twitter.com/CriticalStress_/status/14829 } \\
\underline{08968918093827 ? \mathrm{~s}=20}\end{array}$ & $\begin{array}{l}\text { Post on social } \\
\text { network }\end{array}$ & World \\
\hline $\begin{array}{l}\text { Can you stand in a knee } \\
\text { high \#tsunami? }\end{array}$ & $\begin{array}{l}\text { https://twitter.com/JudithGeology/status/14826 } \\
\underline{41594176401412 ? \mathrm{~s}=20}\end{array}$ & $\begin{array}{l}\text { NOTE: It has } \\
\text { nothing to do with } \\
\text { this event, but this } \\
\text { video is relevant }\end{array}$ & \\
\hline $\begin{array}{l}\text { Evidence of a large } \\
\text { tsunami in Tonga in the } \\
15 \text { th century }\end{array}$ & $\begin{array}{l}\text { https://www.frontiersin.org/articles/10.3389/fea } \\
\underline{\text { rt.2021.748755/full }}\end{array}$ & Paper & \\
\hline $\begin{array}{l}\text { Ensenada and } \\
\text { Manzanillo wave } \\
\text { effects }\end{array}$ & $\underline{\underline{\text { https://twitter.com/IsaacRodrgz/status/1482453 }}}$ & $\begin{array}{l}\text { Post on social } \\
\text { network }\end{array}$ & Mexico \\
\hline Effects in Zihuatanejo & $\begin{array}{l}\text { https://www.youtube.com/watch?v=ZriTf- } \\
\underline{\text { nKEA0 }}\end{array}$ & Video & Mexico \\
\hline Effects in Acapulco & https://youtu.be/OMf51Dioy90 & Video & Mexico \\
\hline $\begin{array}{l}\text { General interview } \\
\text { effects in Mexico }\end{array}$ & https://youtu.be/5W3-LzcibiY & Video & Mexico \\
\hline
\end{tabular}

